\title{
Grundtvig-Studier 1968
}

udgør det 2 I. bind af Grundtvig-Selskabets kendte årsskrift og indleder således en 3. række af denne skriftserie.

Det indledes med en afhandling om Grundtvig og Jylland af professor, dr. phil. Gustav Albeck, Århus. Bindet indeholder endvidere 2 afhandlinger af bibliotekar, cand. mag. Steen Johansen, København, den ene om Familiestriden 1872-73 om N. F. S. Grundtvigs efterladte papirer, den anden om tilblivelsen af Grundtvigs oversættelse af Saxo og Snorre i anledning af, at det i 1968 var 150 år, siden Grundtvig udsendte I. bind af sine berømte oversættelser. Amanuensis Andreas Haarder, Århus, offentliggør en interessant undersøgelse kaldet Syv Beowulf-anmeldere, sluttende med Grundtvigs anmeldelse, som »er af en kvalitet, der placerer den i særklasse«. Årgangen indeholder desuden et bibliografisk tillæg om Grundtvig-litteraturen $1963-68$ ved universitetsadjunkt Aage Jørgensen, Arhus, samt en anmeldelse af 3 . bind af Uffe Hansen: Grundtvigs Salmedigtning ved universitetslektor Kristian Kjær, Gøteborg.

Tidligere udkom:

Grundtvig-Studier 1948. Gyldendal. I 6 s. Grundtvig-Studier 1949. Gyldendal. I I 2 s. Grundtvig-Studier 1950. Gyldendal. I 12 s. Grundtvig-Studier 195 I. Gyldendal. I 32 s. Grundtvig-Studier 1952. Gyldendal. I 08 s. Grundtvig-Studier 1953. Gyldendal. I 28 s. Grundtvig-Studier 1954. Gyldendal. i 6 s. Grundtvig-Studier 1955. Gyldendal. I 20 s. Grundtvig-Studier 1956. Gyldendal. I 6 s. Grundtvig-Studier 1957. Gyldendal. I32 s. Grundtvig-Studier 1958. Gyldendal. 124 s.

Grundtvig-Studier 1959. Gyldendal. I $24 \mathrm{~s}$. Grundtvig-Studier 196o. Gyldendal. $92 \mathrm{~s}$. Grundtvig-Studier 196r. Gyldendal. I 22 s. Grundtvig-Studier 1962. Gyldendal. I $04 \mathrm{~s}$. Grundtvig-Studier 1963. Gyldendal. $84 \mathrm{~s}$. Grundtvig-Studier 1 964 . Gyldendal. I 16 s. Grundtvig-Studier 1965. Gyldendal. I 20 s. Grundtvig-Studier I 966. D. B. K. I I 2 s. Grundtvig-Studier i 967 . D. B. K. I I 0 s. Grundtvig-Studier i 968 . D. B. K. 96 s.

I serien Skrifter udgivet af Grundtvig-Selskabet er hidtil udkommet:

1. Henning Høirup: Grundtvigs Syn paa Tro og Erkendelse. Gyldendal 1949. 420 sider.

II. Helge Toldberg: Grundtvigs symbolverden. Gyldendal I950. XII +356 sider.

III. Magnus Stevns: Fra Grundtvigs Salmevarksted. Udgivet af Henning Høirup og Steen Johansen. Gyldendal I 950 .

IV. Villiam Grønbak: Psykologiske tanker og teorier hos Grundtvig. Gyldendal I95 I. 192 sider.

V. Carl Weltzer: Grundtvig og Søren Kierkegaard. Gyldendal I 952.96 sider.

VI. William Michelsen: Tilblivelsen af Grundtvigs historiesyn. Gyldendal i954. 368 sider.

VII. Henning Høirup: Fra døden til livet, Grundtvigs tanker om liv og død. Gyldendal 1954. I 2 sider.

VIII. Niels Kofoed: Grundtvig som selvbiograf. Gyldendal 1954. I 36 sider.

IX. William Michelsen: Den salsomme forvandling $i$ N.F.S. Grundtvigs liv. Gyldendal 1956. 288 sider.

X. N.F.S. Grundtvig: Taler paa Marielyst Højskole I856-7 I, udgivet af Steen Fohansen. Gyldendal 1956. I 6 sider.

XI. Harry Aronson: Mänskligt och kristet. En studie i Grundtvigs teologi. Bonnier 1960. 312 sider.

XII. Sigurd Aa. Aarnes: Historieskrivning og livssyn hos Grundtvig. Oslo 1962.

XIII. Kaj Thaning: Menneske forst - I-III. Gyldendal 1963.

XIV. Flemming Lundgreen-Nielsen: N. F. S. Grundtvig. Skabne og Forsyn. Gyldendal i 965.

Til Grundtvig-Selskabet er overgået:

II a. Helge Toldberg: Grundtvig som filolog. G. E. G. Gad I 946. I 52 sider. 